\title{
CARA BERPIKIR DALAM MENYELESAIKAN SOAL-SOAL SELANG, KETAKSAMAAN DAN NILAI MUTLAK
}

\author{
Marhamah \\ Pendidikan Matematika Universitas PGRI Palembang \\ Marhamah1904@gmail.com
}

\begin{abstract}
Inequality is a mathematical statement that contains one of the sequence relations $<,>, \leq, \geq$. This sequence relation has been known by students since they were in elementary school, junior high school, senior high school and even went to university. In Higher Education material lapse, inequality and absolute grades are found in Differential Calculus courses and become one of the prerequisites for other courses namely Differential Calculus. Based on our observations at the Mathematics Education Study Program FKIP Palembang PGRI University, the understanding of solving interval questions, inequality and absolute values cannot be understood well by students, which we conclude that students still feel confused and make many mistakes in solving problems a matter of lapse, inequality and absolute value. In this description, we present how to think in solving intervals, inaccuracies and absolute values so that students can solve these problems.

Keywords: how to think with intervals, inequality, absolute value.
\end{abstract}

\begin{abstract}
Abstrak
Ketaksamaan adalah pernyataan matematik yang memuat salah satu relasi urutan $<,>, \leq$, $\geq$. Relasi urutan tersebut sudah dikenal siswa sejak duduk di bangku Sekolah Dasar, Sekolah Menengah Pertama, Sekolah Menengah Atas bahkan sampai ke Perguruan Tinggi. Di Perguruan Tinggi materi selang, ketaksamaan dan nilai mutlak terdapat pada mata kuliah Kalkulus Diferensial dan menjadi salah satu prasyarat bagi mata kuliah yang lain yaitu Kalkulus Diferensial. Berdasarkan pengamatan kami di Program Studi Pendidikan Matematika FKIP Universitas PGRI Palembang, pemahaman tentang penyelesaian soal-soal selang, ketaksamaan dan nilai mutlak belum dapat dipahami dengan baik oleh mahasiswa, yang mana kami berkesimpulan bahwa mahasiswa masih merasa bingung dan banyak melakukan kesalahan dalam menyelesaikan soal-soal tentang selang, ketaksamaan dan nilai mutlak. Dalam uraian ini kami kemukakan bagaimana cara berpikir dalam menyelesaikan soal-soal selang, ketaksamaan dan nilai mutlak sehingga mahasiswa bisa menyelsaikan persoalan tersebut.
\end{abstract}

Kata Kunci : cara berpikir dengan selang, ketaksamaan, nilai mutlak.

\section{PENDAHULUAN}

Pemahaman mengenai relasi urutan ketaksamaan di tingkat SD, SMP dan SMA sedikit banyak mempengaruhi pemahaman materi selang, ketaksamaan dan nilai mutlak yang terdapat mata mata kuliah kalkulus diferensial tingkat Perguruan Tinggi khususnya pada Program Studi Pendidikan Matematika. Materi selang, ketaksamaan dan nilai mutlak ini saling berkaitan karena untuk bisa menyelesaikan soal-soal tersebut mahasiswa harus benar benar memahami ketaksamaan. Menurut Soedjadi (2000) tujuan diajarkan matematika disetiap jenjang pendidikan meliputi tujuan bersifat formal dan material. Tujuan formal menekankan pada penataan nalar dan pembentukan kepribadian, sedangkan tujuan material menekankan pada keterampilan matematika sekaligus menerapkannya.

Tujuan diajarkan matematika bagi mahasiswa calon guru Pendidikan Matematika di Universitas PGRI Palembnag lebih menekankan pada tujuan yang bersifat material yakni mahasiswa nantinya diharapkan memiliki bekal materi yang memadai pada saat menjadi guru nantinya.

Berdasarkan pengamatan kami di Program Studi Pendidikan Matematika FKIP Universitas PGRI Palembang, pemahaman tentang penyelesaian soal-soal selang, ketaksamaan dan nilai mutlak belum dapat dipahami dengan baik oleh mahasiswa, yang mana kami berkesimpulan bahwa mahasiswa masih merasa bingung dan banyak melakukan kesalahan dalam menyelesaikan soal-soal tentang selang, ketaksamaan dan nilai mutlak, padahal ketiganya itu saling berkaitan misalkan diberikan 
soal tentang hubungan nilai mutlak dengan ketaksamaan, dimana pertanyaannya diminta untuk menentukan selang, penulisan himpunan dan grafik. Untuk menyelesaikan pertanyaan tersebut maka mahasiswa harus benar benar memahami tentang ketaksamaan.

\section{PEMBAHASAN}

Menyelesaikan suatu ketaksamaan ialah mencari semua himpunan bilangan rill yang membuat ketaksamaan itu berlaku. Berbeda dengan persamaan yang dimana himpunan pemecahannya secara normal terdiri dari suatu bilangan atau mungkin sejumlah bilangan terhingga, dalam pemecahan suatu ketaksamaan itu biasanya terdiri dari suatu keseluruhan selang bilangan atau gabungan dari keseluruhan selang-selang.

\section{A. BAGAIMANA CARA BERPIKIR DALAM PENULISAN SELANG BILANGAN}

Sebelum kita menyelesaikan cara penulisan selang, terlebih dahulu kita harus memahami bahwa dalam pemecahan suatu ketaksamaan biasanya terdiri dari suatu keseluruhan selang bilangan atau gabungan dari keseluruhan selang-selang dan dalam ketaksamaan ada dua jenis selang.

Dua jenis selang dalam ketaksamaan

\section{a. Selang Terbuka}

Ketaksamaan ganda $\mathrm{a}<\mathrm{x}<\mathrm{b}$ memerikan selang terbuka yang terdiri dari semua bilangan antara a dan $b$, tidak termasuk titik-titik ujung a dan $b$ dan dinyatakan dengan lambang (a, b). Penulisan selang terbuka dengan menggunakan kurung biasa.

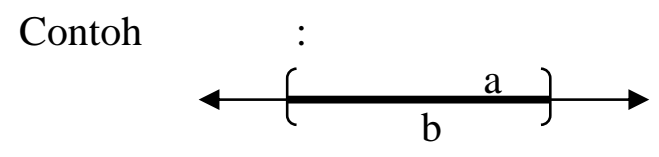

$$
\begin{array}{ll}
\text { Penulisan selang } & :(\mathrm{a}, \mathrm{b}) \\
\text { Penulisan himpunan } & :\{\mathrm{x}: \mathrm{a}<\mathrm{x}<\mathrm{b}\}
\end{array}
$$

\section{b. Selang Tertutup}

Ketaksamaan $\mathrm{a} \leq \mathrm{x} \leq \mathrm{b}$ memerikan selang tertutup yang berpadanan yang mencakup titik-titik ujung a dan $b$ dan dinyatakan dengan lambang [a,b]

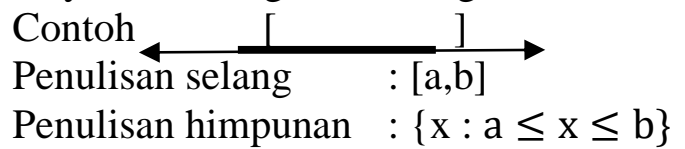

Dalam penulisan selang bilangan ada beberapa hal yang harus kita perhatikan :

1) Tanda relasi ketaksamaan, apabila menggunakan tanda < atau > maka kurung yang digunakan adalah kurung biasa, sedangkan apabila tanda relasi ketaksamaan $\leq$ atau $\geq$ kurung yang digunakan adalah kurung siku.

Contoh : $2<x<6$, dibaca : $x$ lebih dari 2 kurang dari 6 , tidak ada tanda samadengan pada ketaksamaan tersebut, maka menggunakan kurung biasa, penulisan selangnya $(2,6)$.

2) Apabila yang diketahui penulisan selang dan mau di ubah menjadi penulisan himpunan maka harus memperhatikan kurung yang terdapat pada penulisan selang, apabila menggunakan kurung biasa maka relasi ketaksamaannya adalah < atau $>$, apabila menggunakan kurung siku maka relasi ketaksamaannya adalah $\leq$ atau $\geq$.

Contoh : $2 \leq x \leq 6$, dibaca : $\mathrm{x}$ lebih dari atau samadengan 2, x kurang dari atau samadengan 6, karena ada tanda samadengan maka menggunakan kurung siku, penulisan selangnya $[2,6]$.

Setelah kita mengetahui kedua jenis selang tersebut, maka kita harus mengetahui sejumlah besar kemungkinan dari penulisan himpunan, penulisan selang dan grafik seperti yang ditunjukkan pada tabel berikut :

Tabel

yang menunjukkan sejumlah besar kemungkinan

\begin{tabular}{|c|c|c|c|}
\hline No & Penulisan Himpunan & Penulisan Selang & \multicolumn{2}{|c|}{ Grafik } \\
\hline 1 & $\{x: a<x<b\}$ & $(a, b)$ & $\frac{(a}{b}$ \\
\hline 2 & $\{x: a \leq x \leq b\}$ & {$[a, b]$} & $\frac{1}{b}$ \\
\hline 3 & $\{x: a \leq x<b\}$ & {$[a, b)$} & $\frac{a}{+}$ \\
\hline 4 & $\{x: a<x \leq b\}$ & $(a, b]$ & $\frac{a}{+}$ \\
\hline
\end{tabular}




\begin{tabular}{|c|c|c|c|}
\hline & & & $a \quad b$ \\
\hline 5 & $\{x: x \leq b\}$ & $(-\infty, b]$ & $\frac{1}{b}$ \\
\hline 6 & $\{x: x<b\}$ & $(-\infty, b)$ & 4 \\
\hline 7 & $\{x: x \geq a\}$ & {$[a, \infty)$} & I \\
\hline 8 & $\{x: x>a\}$ & $(a, \infty)$ & $A$ \\
\hline 9 & $R$ & $(-\infty, \infty)$ & $\underset{a}{L}$ \\
\hline
\end{tabular}

B. BAGAIMANA CARA BERPIKIR

DALAM MENYELESAIKAN SOAL KETAKSAMAAN

1. Untuk soal linear atau pangkat satu

Untuk soal linier, pisahkan ruas antara variabel dan konstanta

Contoh :

$$
\begin{aligned}
4 \mathrm{x}+5 & <-3 \\
4 \mathrm{x} & <-8 \\
\mathrm{x} & <-2
\end{aligned}
$$

Penulisan selang

$$
(-\infty,-2)
$$

Penulisan himpunan $\quad: \quad\{\mathrm{x}: \mathrm{x}<$

$$
-2\}
$$

\section{Untuk soal kuadrat atau lebih dan} pecahan

Langkah-langkahnya:

a. Buat ruas kanan menjadi nol.

b. Koefisien pangkat tertinggi dibuat menjadi positif.

c. Faktorkan ruas kiri.

d. Cari titik pemecahan.

e. Uji titik-titik diantara titik pemecah.

f. Jika relasi "kurang dari" ambil daerah yang negatif.

Jika relasi "lebih dari" ambil daerah yang positif.

Jika ada tanda $=($ sama dengan $)$ titik pecah diuji:
Jika $=0$ maka memenuhi dengan menggunakan kurung siku.

Jika $\neq 0$, maka tidak memenuhi dan gunakan kurung biasa.

g. Gambar grafik, tulis selang dan himpunannya (yang menjadi himpunan penyelesaian adalah titik-titik pemecah bukan pada titik uji)

h. Khusus pecahan samakan penyebutnya.

Contoh :

1. Selesaikan ketaksamaan $x^{2}+$ $\mathrm{x}<2$

Jawab :

Langkah-langkahnya:

a. Buat ruas kanan menjadi nol.

$\mathrm{x}^{2}+\mathrm{x}<2$

$x^{2}+x-2<0$

b. Koefisien pangkat tertinggi sudah positif

c. Faktorkan ruas kiri $\mathrm{x}^{2}+\mathrm{x}-2<0$ $(x+2)(x-1)<0$

d. Titik - titik pemecah $(x+2)(x-1)<0$ $\mathrm{x}=-2$ atau $\mathrm{x}=1$ titik-titik pemecah $x=-2$ dan $\mathrm{x}=1$

e. Uji dintara titik pemecah

f. 


\begin{tabular}{|c|c|c|}
\hline Titik uji & Nilai dari $(\mathrm{x}+2)(\mathrm{x}-1)$ & Tanda \\
\hline-3 & 4 & + \\
0 & -2 & - \\
2 & 4 & + \\
& & \\
\hline
\end{tabular}

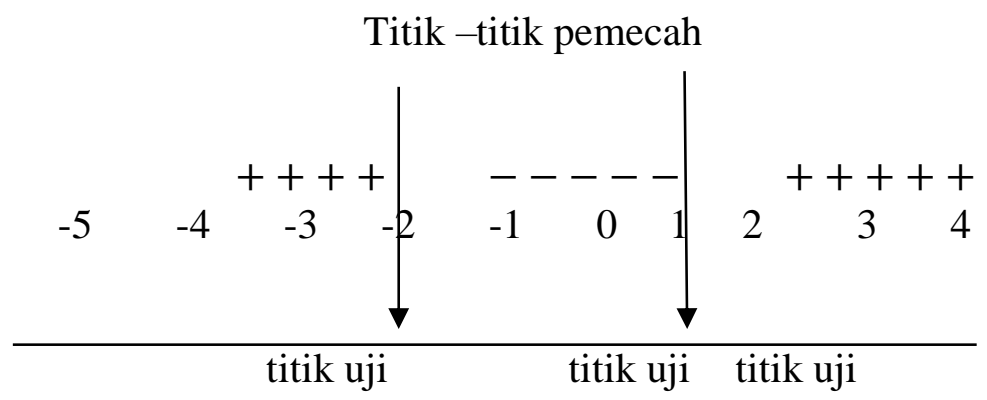

g. Gambar grafik, tulis selang dan himpunannya.

Penulisan selang

Penulisan himpunan

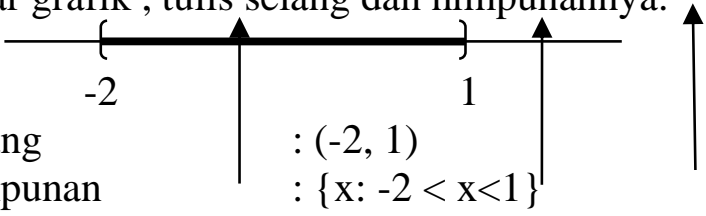

\section{BAGAIMANA CARA BERPIKIR DALAM MENYELESAIKAN SOAL NILAI MUTLAK DAN} KETAKSAMAAN

Untuk menyelesaikan soal nilai mutlak dan ketaksamaan maka terlebih dahulu kita harus mengetahui dan memahami hubungan nilai mutlak dengan ketaksamaan. Seringkali mahasiswa dalam menyelesaikan soal nilai mutlak dan ketaksamaan tidak memperhatikan tanda ketaksamaan pada soal.

\section{Hubungan nilai mutlak dengan}

\section{Ketaksamaan}

1. Jika $|\mathrm{x}|<\mathrm{a}$ maka $-\mathrm{a}<\mathrm{x}<\mathrm{a}$

2. Jika $|x|>$ a maka $\mathrm{x}<-\mathrm{a}$ atau $\mathrm{x}>\mathrm{a}$

Seringkali mahasiswa dalam menyelesaikan ketaksamaan

Contoh :

$$
\text { 1. }\left|2+\frac{5}{x}\right|>1
$$

Pada soal di atas tanda ketaksamaan yang digunakan adalah >, berdasarkan hubungan nilai mutlak dengan ketaksamaan maka menggunakan hubungan nilai mutlak dengan ketaksamaan pada no 2.

$$
\begin{gathered}
\left(2+\frac{5}{x}\right)>1 \quad \text { Atau } \\
\left(2+\frac{5}{x}\right)<-1
\end{gathered}
$$

$$
\begin{aligned}
& \frac{5}{\mathrm{x}}+1>0 \\
& \frac{5}{x}+3<0 \\
& \frac{5+\mathrm{x}}{\mathrm{x}}>0 \\
& \frac{5+3 x}{x}<0 \\
& \mathrm{x}=-5 \cdot \mathrm{x}=0 \\
& \frac{-5}{3} \cdot x=0
\end{aligned}
$$

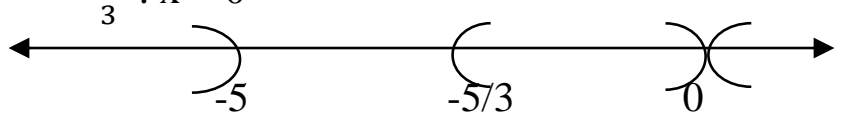

$$
\begin{aligned}
& \text { Penulisan selang } \quad:(-\infty,-5) \cup(- \\
& \left.\frac{5}{3}, 0\right)(0, \infty)
\end{aligned}
$$

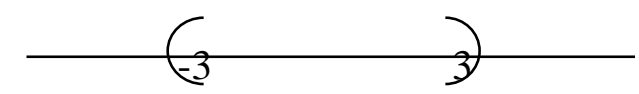

Penulisan selang $:(-3,3)$

Penulisan himpunan : $\{\mathrm{x}:-3<\mathrm{x}<3\}$ 
Dari uraian yang sudah kami kemukakan, beberapa hal yang dapat diambil kesimpulan, yaitu sebagai berikut :

a. Cermati terlebih dahulu setiap soal yang diberikan.

b. Dalam penulisan selang perhatikan tanda ketaksamaan yang terdapat pada soal

c. Dalam penyelesaian ketaksamaan perhatikan tipe soal, apakah untuk soal linier, soal kuadrat atau lebih dan pecahan.

d. Untuk menyelesaikan soal nilai mutlak dan ketaksamaan maka terlebih dahulu kita harus mengetahui dan memahami hubungan nilai mutlak dengan ketaksamaan.

\section{DAFTAR PUSTAKA}

Frank Ayres Gr. 1990. Teori dan Soal-soal Diferensial dan Integral Kalkulus, Edisi ke-2. Jakarta : Erlangga

Mursita. Danang. 2004. Matematika Dasar Untuk Perguruan Tinggi. Bandung; Rekayasa Sains.

Purcell Edwin G. Dan Varberg Dali. 1995. Kalkulus dan Geometri Analisis Jilid 1, Edisi Ke-5. Jakarta : Erlangga

Soedjadi, R. 2000. Kiat Pendidikan Matematika di Indonesia (Konstansi Keadaan Masa Kini Menuju Keadaan Masa Depan). Dikti : Jakarta.

Soemartojo, Nunik. 1992. Kalkulus Dasar, Edisi Ke-2. Fakultas Ekonomi Universitas Indoniseia Jakarta. 